\title{
AN OVERVIEW OF INDUSTRIAL AND ORGANISATIONAL PSYCHOLOGY RESEARCH in SOUTh Africa: A preliminary STUdy
}

\author{
Authors: \\ Dries Schreuder ${ }^{1}$ \\ Melinde Coetzee
}

\section{Affiliations:}

${ }^{1}$ Department of Industrial and Organisational Psychology, University of South Africa, Pretoria, South Africa

\section{Correspondence to:}

Melinde Coetzee

email:

coetzm1@unisa.ac.za

\section{Postal address:}

Department of Industrial and Organisational

Psychology, PO Box 392,

UNISA 0003, South Africa

\section{Keywords:}

career psychology;

employee- and

organisational well-being; personnel psychology; psychometrics;

organisational psychology

\section{Dates:}

Received: 06 Apr. 2010 Accepted: 02 Aug. 2010

Published: 22 Oct. 2010

How to cite this article: Schreuder, D., \& Coetzee M. (2010). An overview of industrial and organisational psychology research in South Africa: A preliminary study. SA Journal of Industrial Psychology/SA Tydskrif vir Bedryfsielkunde, 36(1), Art. \#903, 11 pages. DOI: 10.4102/sajip.v36i1.903

This article is available at: http://www.sajip.co.za

(c) 2010. The Authors. Licensee: OpenJournals Publishing. This work is licensed under the Creative Commons Attribution License.

\section{ABSTRACT}

Orientation: The generation and development of knowledge for the benefit of the discipline of industrial and organisational psychology by means of research is a core academic focus.

Research purpose: The purpose of this study was to explore general research trends in the field of industrial and organisational psychology in South Africa from 1950 to 2008.

Motivation for study: Research in the field tends to be influenced by either the changing needs of business or the occupational or personal fields of interest of academics, which often lead to an overemphasis on specific subdisciplines at the expense of others. This research aims to critically review dominant trends in the research focus areas in the field, in the light of present challenges in the changing work context. Recommendations are also made for possible future research.

Research design, approach and method: A broad systematic review was carried out to analyse documented published and accredited South African research in the field $(n=2501)$.

Main findings: Although there has been a proportional decline in personnel psychology research since 1990, there has been a proportional increase in both organisational psychology and employee wellness research since 1980 and 1990, respectively. Some areas of the industrial and organisational psychology field appear to be consistently under-researched.

Practical implications: The insights derived from the findings can be used by academia and researchers in the field to plan future research initiatives.

Contribution/value-add: The findings provide preliminary insights that contribute to the body of knowledge concerned with the industrial and organisational psychology field in the South African context.

\section{INTRODUCTION}

\section{Key focus of the study}

Industrial and organisational (I/O) psychology as an applied division of psychology is both an academic and an applied field concerned with the study of human behaviour related to work, organisations and productivity in a particular type of location, that is, almost any kind of organisation (Cascio, 2001; SIOP, 1999). In the academic field, different topics in the various subfields of I/O psychology are studied (both theoretically and empirically) to generate new knowledge and solutions, with a view to addressing the critical challenges and issues stemming from the particular socio-economic contexts in which organisations are located. Applied I/O psychology uses the psychological principles and the new knowledge and solutions generated by research to solve problems in the work context (Bergh, 2009; Coetzee \& Schreuder, 2010). The present study is located within the academic domain and focuses on research trends from 1950 to 2008 in I/O psychology as an established discipline in the South African context.

\section{Background to the study}

As depicted in Figure 1, I/O psychology and its research focus areas have evolved to address the changing needs of societies and organisations and to generate new knowledge and technology with a view to dealing with the demands of globally and nationally changing contexts. As far as the field's historical roots are concerned, research in I/O psychology in the United States started to evolve at the beginning of the 20th century when the United States entered the First World War and the testing and placement of army recruits became important (Landy \& Conte, 2010). Studies in personnel selection, work methods and job design were originally carried out as early as 1913 (Katzell \& Austin, 1992), and continued to be important during and after the Second World War. While the knowledge base and techniques for applying selection, placement, evaluation and appraisal to specific situations were refined during World War II, and the mid-1960s to the mid-1980s, organisational psychology took on the role of equal partner with industrial psychology, and hence the reference to the field as I/O psychology (Levy, 2006). Areas such as organisational dynamics, work groups and leadership, and employee morale also became important focus areas, along with improving productivity and reducing counterproductive behaviour such as absenteeism and turnover (Landy \& Conte, 2010). During the mid-1960s to mid1980s organisational topics such as work motivation, job attitudes and job characteristics also became prominent, along with a continued interest in mental ability tests (Levy, 2006).

During the last $15-20$ years (the mid-1980s to the present), the field of I/O psychology has grown very rapidly in the United States, where the focus has been on traditional areas such as selection, Performance appraisal, motivation and leadership, as well as in new domains such as the fairness of employment tests and the legal climate involved in personnel and labour law (Levy, 2006). Personality characteristics are 


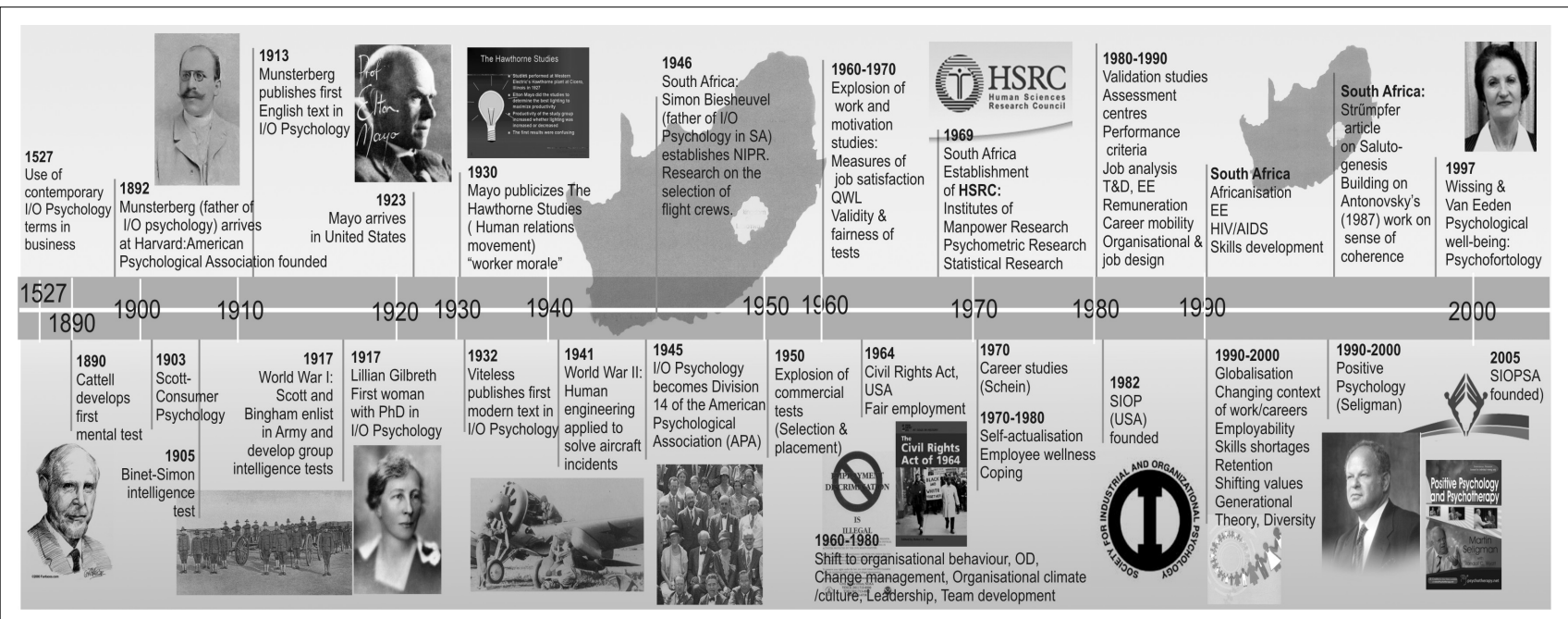

Source: Schreuder, A.M.G., \& Coetzee, M. (2009). A historical overview of research on I/O sychology in South Africa. Poster presented at SIOPSA 12th Annual Conference, June, CSIR, Pretoria. FIGURE 1

Overview of the historical evolution of Industrial and organisational psychology

assuming an increasingly important role in understanding and predicting work behaviour. Issues of worker well-being, workfamily balance, the experience of work by workers, an ageing workforce, multi-cultural and cross-cultural issues, ethical leader behaviour and world poverty are currently some of the emerging trends in the United States (Landy \& Conte, 2010).

In 1946 research in I/O psychology came into its own in South Africa with the establishment of the National Institute for Personnel Research (NIPR). Since then, studies have been undertaken into a wide range of subjects related to the various subdisciplines in the field. Simon Biesheuvel (the then Director of the NIPR) is generally regarded as the father of industrial psychology in South Africa (Schreuder, 2001). His research on the selection of flight crews and his presentation of a number of scientific papers made him one of the most respected psychological researchers in the country (Biesheuvel, 1984). The establishment of the Human Sciences Research Council (HSRC) in 1969, and the research that subsequently followed, made a significant contribution to the development of the I/O psychology discipline in South Africa. The research contributions of the HSRC's Institute of Manpower Research and Institute of Statistical Research were particularly significant to the evolution of I/O psychology in South Africa (Raubenheimer, 1974)

Historically, numerous researchers have questioned the extent to which I/O psychology research was needs-driven and problem-orientated (Augustyn \& Cillié, 2008; Katzell \& Austin, 1992; Moalusi, 2001; Pietersen, 2005; Schreuder, 2001; Sweder \& Fiske 1986; Van Vuuren, 2006; Veldsman, 2001). Dunnette (1990) asked whether practitioners of I/O psychology are using the best the field has to offer and whether the science and practice of the discipline have a synergistic impact on each other. $\mathrm{He}$ came to the unsettling conclusion that I/O psychology is not faring well. He blamed this state of affairs on, among other things, the burden of the publication process, and continued by saying that the published material does clearly suggest that a potentially serious schism exists between the academic (science) and applied (practice) aspects of the discipline.

According to Augustyn and Cillié (2008), the schism between science and practice still exists in South Africa. They argue that the research contributions of academics and practitioners are often not needs-driven and problem-orientated; instead, academics and practitioners seem rather to 'keep their pets, have their fun, suffer their delusions, keep their secrets, and ask their questions' (Augustyn \& Cillié, 2008, p. 71). Research in the I/O psychology field often appears to be a function of data availability - the norm being the recycling of available data in the pursuit of 'hot topics'. In academic circles, those who try to apply knowledge in their teaching and consulting to organisations are often (almost bizarrely) labelled 'practitioners', while their colleagues who publish (irrespective of the quality or the usefulness of the publications) are labelled 'academics'. Driven by the zeal to either 'publish or perish', academics appear to be mostly concerned about the quantity rather than the actual relevance of their research outputs. Augustyn and Cillié (2008) posit that what is often missing in research publications is convincing arguments for the significance of the research questions - often leaving readers with the question 'so what?' As a result, published research is, in reality, often discounted by the captains of industry 'as a waste of time' (Augustyn \& Cillié, 2008, p.71); industry often regards research contributions as impractical and of little relevance in solving the people-related business problems that occur in industry and commerce.

\section{Research purpose}

As noted earlier, research in $\mathrm{I} / \mathrm{O}$ psychology tends to be influenced by either the shifting needs of business and the occupational or the personal fields of interest of academics, which often leads to an overemphasis on specific subdisciplines at the expense of others. The purpose of the present study is to explore trends in research focus areas in the field of $\mathrm{I} / \mathrm{O}$ psychology in South Africa from 1950 to 2008, and to critically review the dominant trends in the light of present challenges in the changing work context.

\section{Trends from the research literature Industrial and organisational psychology and subdisciplines}

Industrial and organisational psychology can be defined as the scientific study of people within their work environment, which includes the application of psychological principles, theory and research to the work setting (Landy \& Conte, 2004; Riggio, 2009). I/O psychology has two objectives: firstly, to conduct research in an effort to increase knowledge and understanding of human work behaviour; and secondly, to apply that knowledge to improve work behaviour, the work environment and the psychological conditions of workers. In other words, I/O psychologists are trained to be both scientists and practitioners, in what is referred to as the scientistpractitioner model (Riggio, 2009).

Although the name of the field is not a generally agreed-upon issue (Bergh, 2009), the term 'organisational psychology' was added to the original term 'industrial psychology' only in 
the 1970s (Muchinsky, Kriek \& Schreuder, 2005). Industrial psychology, historically called personnel psychology, is the study of how individuals behave within work settings. Organisational psychology is closely related to industrial or personnel psychology, and concerns the study of work at the organisational level, to understand how workers function in an organisation and how the organisation functions as a whole (Coetzee \& Schreuder, 2010).

According to the Health Professions Council of South Africa (HPCSA), the coordinating body for all registered health professions (including psychologists) in South Africa, industrial psychologists practise in business or industrial settings with the general aim of directly benefiting the economic well-being of the organisation. They are concerned with people functioning effectively in relation to their working environments. Their areas of expertise include:

- recruitment and selection

- training, appraisal and review

- vocational guidance and career development

- industrial relations

- occupational health and safety

- planning technological and organisational change

- organisational behaviour

- ergonomics

- consumer behaviour

- job redesign

- marketing.

(HPCSA, n.d.)

For the purpose of the present study the following recognised fields of I/O psychology were used as a framework for determining research trends in the field (Landy \& Conte, 2010).

Personnel psychology is regarded as one of the oldest and more traditional fields of I/O psychology (Muchinsky et al., 2005). This field is concerned with the scientific study of individual differences in work settings, and includes activities such as job analysis and criterion development; psychological assessment, employee selection and placement; employee reward and remuneration; employee training and development; career development support; employee performance evaluation; attracting and retaining scarce and critical talent; and encouraging adherence to employment-related legislation. As a subdiscipline of I/O psychology, personnel psychology represents the overlap between psychology and human resource management (Coetzee \& Schreuder, 2010).

Organisational psychology focuses on the influence organisations have on the attitudes and behaviour of their employees. While personnel psychology is more concerned with individuallevel issues, organisational psychology aims to study work at the organisational level in order to understand how workers function in an organisation and how the organisation functions as a whole. Typical activities include: the promotion of job satisfaction, group dynamics and teamwork, decision-making, inter-personal conflict, motivation, power, communication, organisational change, culture and climate, organisational citizenship behaviour, organisational commitment and employee engagement, quality of work life, employee and organisational wellness, leadership development and training, and organisational design, structure and development (Bergh, 2009; Coetzee \& Schreuder, 2010).

Career psychology is concerned with the interplay between individuals and environments and attempts to describe the nature of the patterns of positions held and resultant experiences during an individual's lifespan (Arnold \& Randall, 2010). This subdiscipline focuses on providing models and explanations for organisational career-related activities such as the following:

- the origin and measurement of individual aptitudes

- personality
- interests and career orientations

- motives and values' how individual, social, chance and environmental factors shape educational and training experiences

- employee employability

- career embeddedness and mobility

- experiences of career well-being

- job and career satisfaction

- career agency

- early work history

- occupational choice

- organisational/job choice and career movements after organisational entry

- $\quad$ work/family issues

- career plateaus

- retirement planning.

(SIOP, 1999)

Knowledge of organisational practices related to personnel psychology and organisational psychology (i.e. I/O psychology) assist in understanding specific career issues and challenges faced by certain groups such as people with disabilities women and historically disadvantaged ethnic groups (Coetzee, 2010; SIOP, 1999).

Psychological assessment involves psychometrics, which refers to the development and utilisation of various types of assessment instruments to measure, predict, interpret and communicate distinguishing characteristics of individuals for a variety of work-related purposes, such as selection (hiring, promotion, placement), successful work performance and development (career planning, skill and competency building, rehabilitation, employee counselling). The psychological assessment of individuals may help the organisation achieve personenvironment fit and person-job/career fit within the specific organisational context (department or work group) (Bergh, 2009; SIOP, 1999).

Ergonomics is concerned with the human-machine interface or the interactions between humans and systems, such as production systems, communication networks and decisionmaking processes. The focus is on the design of equipment, IT systems, human-computer interaction, workplaces and the work itself, and specifically takes into account human factors such as physique, intelligence, emotion and patterns of social interaction (Bergh, 2009). The underlying goal is to modify the work environment so that it is more compatible with the characteristics of human beings, thus obtaining a better fit between humans and their work-related activities (Macleod, 1995). Ergonomics also studies the interactions between human physical capabilities and problematic conditions related to the health and safety of employees in the workplace in an attempt to understand the limits of performance and the negative effects of certain factors on workers. These factors include hazardous environmental conditions, such as those caused by toxic substances, loud noises, blinding light and noxious odours (SIOP, 1999).

Consumer psychology is the study of the psychological aspects of consumer behaviour. It is the systematic study of the relationship between the producers or distributors and consumers (actual or potential recipients) of goods and services. This may involve market research into consumer product preferences, consumer attitudes and motivation, buying habits and patterns, brand preferences, media research (including the effectiveness of advertisements and commercials), estimating the demand for products or services, and the study of people's economic expectations (SIOP, 1999).

Employee and organisational well-being (also referred to as occupational mental health or wellness) is located within the positive psychology paradigm and overlaps to a degree with health and safety management and intervention training. The 
positive psychology paradigm focuses on facilitating positive psychological capital or resources in organisations and employees regarded as important in keeping them healthy and resilient to hardships. Health-promoting factors that are encouraged are an internal locus of control, positive emotions, hope, optimism, self-efficacy, personal hardiness and a sense of coherence (Bergh, 2009). Stress-related factors studied are organisational structure and job design, such as shift work, or the requirements of particular tasks and sources of organisational stress that may influence performance, commitment and attitudinal variables related to downsizing, harassment, work-family pressures and outsourcing (SIOP, 1999). Stress, job burnout, violation of psychological contracts, job insecurity and downsizing remain the most popular topics for study in I/O psychology (Rothmann \& Cilliers, 2007). Employee wellness has become a popular field of the study in I/O psychology since 1990.

Employment relations, better known as labour or industrial relations, is concerned with issues related to the following: the psycho-social dynamics involved in discipline and dismissal, and grievance handling; employment issues such as selection, promotion, remuneration, retrenchment or lay-offs; the behavioural dynamics involved in the union-management cooperation processes such as trade union membership industrial action such as strikes and negotiation, and disputeresolution processes such as mediation (Schreuder \& Coetzee, 2010)

\section{Present challenges for research in Industrial and} organisational psychology

The changing nature of the workplace implies wide and deep changes of emphasis across most areas of I/O psychology. Arnold and Randall (2010) note some of the changes in the world of work and suggest some consequences for what are, or should be, focus areas of research within I/O psychology. These are listed in Table 1 below.

In the South African context, of particular interest to the field of I/O psychology is also the South African National Research and Development Strategy's (NRSD) current emphasis on certain research initiatives. These initiatives help drive South Africa's transformation towards becoming a knowledge-based economy in which the production and dissemination of knowledge enriches all fields of human endeavour and leads to economic benefits such as productivity, economic growth and socioeconomic development (DHET, 2010; DST, 2008). According to the NRSD, the results of scientific research must, among other things, address human capital development, help produce knowledge workers capable of building a globally competitive environment, and contribute to a greater understanding of the shifting human and socio-political dynamics in South African workplaces and communities (DST, 2008).

I/O psychology in South Africa should consider the sociopolitical uniqueness of the country in its research agenda. These include research initiatives focused on strengthening the skills and human resource base in organisations, and improving the health profile of employees by addressing the prevalence of HIV/AIDS in workplaces and communities (DHET, 2010). $\mathrm{I} / \mathrm{O}$ psychologists must recognise the national vision of an inclusive society, implying that research should contribute solutions to further the participation of those groups (women, black people and people with disabilities) that have historically suffered from poverty and disadvantage in decent work and sustainable livelihoods. In addition, youth employment and skills development, and induction to work as a vital bridge into productive and satisfying adulthood, need to be facilitated by research initiatives (DHET, 2010).

Rothmann and Cilliers (2007) posit that diversity has become an important area of research for I/O psychology in South Africa, especially research on the effects of stereotypes, affirmative action and employment equity, prejudices and discrimination on individual wellness, employee relations and organisational effectiveness. They also highlight the importance of research on aspects such as the following: the role of inter-cultural communication, cultural differences, minority positions and migration toward employee and organisational wellness, and the measurement and development of psychological capital, such as a sense of coherence, self-efficacy, optimism, subjective well-being, life satisfaction, resilience, positive affectivity, coping strategies and emotional intelligence.

According to Coutinho, Dam and Blustein (2008), the demands of free-market capitalism, the infusion of technology and the global skills scarcity are on the one hand reducing the need for numerous types of workers but on the other hand increasing concerns about retaining valuable skilled staff (because these are viewed as a scarce resource). These authors therefore believe that it is unlikely that there are enough intrinsically motivating jobs and meaningful work options available to the majority of people. Changing definitions of work, careers and job structure, widespread downsizing, subsequent losses in job security, and highly divergent and diverse career paths have all led to a shift in organisational loyalties and an increased emphasis on career agency (Baruch, 2004; Marshall \& Bonner 2003; Sinclair, 2009; Suutari \& Taka, 2004).

It is apparent that continued research in employee and

TABLE 1

World of work changes and their global implications for Industrial and organisational psychology

\begin{tabular}{|c|c|}
\hline World of work changes & Global implications for I/O psychology (i.e. research focus areas of increasing importance) \\
\hline Ageing working population & Learning, performance, satisfaction and engagement with work of older people \\
\hline $\begin{array}{l}\text { Increasing labour market participation and equality for historically } \\
\text { disadvantaged groups, including ethnic minorities, women and people } \\
\text { with disabilities }\end{array}$ & $\begin{array}{l}\text { Further development of fair selection procedures; the work experiences of members of historically } \\
\text { disadvantaged (affirmative action and employment equity) groups; impact of diversity on workplaces and } \\
\text { organisational performance; diversity policies; inter-group relations at work }\end{array}$ \\
\hline Increasing workloads for people in work & $\begin{array}{l}\text { Stress and pressures at work; burnout and mental health; balance between work and other aspects of life; } \\
\text { effects of workload on thinking and behaviour }\end{array}$ \\
\hline $\begin{array}{l}\text { re people working remotely (e.g. at home) using information and } \\
\text { mmunication technologies }\end{array}$ & $\begin{array}{l}\text { Selection of people suited to home working; supervision and leadership of people not physically present; } \\
\text { impact of isolation on work performance and satisfaction; effective virtual communication and teamwork; } \\
\text { recruitment and selection via the internet }\end{array}$ \\
\hline Pressures on organisations both to cut costs and to use knowledge well & $\begin{array}{l}\text { Impact of these competing pressures (including new technology) on the design of jobs; organisational learning } \\
\text { and knowledge management; stress and pressure at work; innovation and creativity; organisational change }\end{array}$ \\
\hline Downsized, delayered and outsourced organisations & $\begin{array}{l}\text { Fewer and more ambigious organisational career paths; individual coping with change and uncertainty; } \\
\text { relations between 'core' and 'peripheral' workers; working life in small organisations; entrepreneurship }\end{array}$ \\
\hline $\begin{array}{l}\text { (Slow) increase in women's participation in traditionally male-dominated } \\
\text { high-status work }\end{array}$ & $\begin{array}{l}\text { The experience of being a women in a 'man's world'; gender stereotypes; women's career success, rewards } \\
\text { and costs relative to men's; 'feminine' ways of working }\end{array}$ \\
\hline $\begin{array}{l}\text { Reduction in availability of manual work; growth of low-skill service } \\
\text { sector jobs; growing divide between those with marketable skills and } \\
\text { qualifications and those without; global 'war for talent' }\end{array}$ & $\begin{array}{l}\text { The psychological and societal impact of income and wealth differences; the experience and consequences } \\
\text { of unemployment and underemployment; retention of scarce and critical skills and high-potential talent; } \\
\text { employability; career mobility }\end{array}$ \\
\hline $\begin{array}{l}\text { ncreasing internationalisation of organisations and markets; ethical and } \\
\text { esponsible leadership }\end{array}$ & $\begin{array}{l}\text { Cross-cultural comparisons of workplaces; working abroad; interpersonal and intercultural influence; the } \\
\text { appropriateness of selection, etc. procedures across cultures; ethical and responsible decision making and } \\
\text { leader/employee behaviour }\end{array}$ \\
\hline
\end{tabular}

Table is based on Arnold, J., \& Randall, R. (2010). Work psychology: Understanding human behaviour in the workplace. (5th edn.). Harlow, Essex: Pearson Education. 
TABLE 2

Frequencies of dominant research in Industrial and organisational psychology subdisciplines: $1950-2008(N=2501)$

\begin{tabular}{|c|c|c|c|c|c|c|}
\hline \multirow[t]{2}{*}{ Subdiscipline } & \multicolumn{6}{|c|}{$f$} \\
\hline & 1950-1959 & $1960-1969$ & $1970-1979$ & $1980-1989$ & $1990-1999$ & $2000-2008$ \\
\hline \multirow[t]{2}{*}{ Personnel psychology } & 9 & 9 & 65 & 175 & 95 & 79 \\
\hline & $(60 \%)$ & $(40 \%)$ & $(54 \%)$ & $(32 \%)$ & $(11 \%)$ & $(8 \%)$ \\
\hline \multirow[t]{2}{*}{ Organisational psychology } & 1 & 3 & 12 & 106 & 201 & 247 \\
\hline & $(70 \%)$ & $(14 \%)$ & $(10 \%)$ & $(20 \%)$ & $(23 \%)$ & $(26 \%)$ \\
\hline \multirow[t]{2}{*}{ Career psychology } & 2 & 2 & 6 & 44 & 87 & 102 \\
\hline & $(13 \%)$ & $(9 \%)$ & $(5 \%)$ & $(8 \%)$ & $(10 \%)$ & $(11 \%)$ \\
\hline \multirow[t]{2}{*}{ Psychometrics/Psychological assessment } & 2 & 3 & 22 & 90 & 190 & 193 \\
\hline & $(13 \%)$ & $(14 \%)$ & $(18 \%)$ & $(16 \%)$ & $(22 \%)$ & $(21 \%)$ \\
\hline \multirow[t]{2}{*}{ Employee and organisational wellness } & - & 3 & 6 & 55 & 175 & 248 \\
\hline & - & $(14 \%)$ & $(5 \%)$ & $(10 \%)$ & $(20 \%)$ & $(27 \%)$ \\
\hline \multirow[t]{2}{*}{ Consumer psychology } & - & - & 4 & 34 & 66 & 47 \\
\hline & - & - & $(3 \%)$ & $(7 \%)$ & $(8 \%)$ & $(4 \%)$ \\
\hline \multirow[t]{2}{*}{ Ergonomics } & 1 & 2 & 2 & 3 & - & - \\
\hline & $(7 \%)$ & $(9 \%)$ & $(2 \%)$ & $(1 \%)$ & - & - \\
\hline \multirow[t]{2}{*}{ Employee relations } & - & - & 4 & 33 & 51 & 27 \\
\hline & - & - & $(3 \%)$ & $(6 \%)$ & $(6 \%)$ & $(3 \%)$ \\
\hline Total $N$ (sources of data) & 15 & 22 & 121 & 540 & 865 & 938 \\
\hline
\end{tabular}

organisational wellness will be required due to the shifting dynamics of work and careers in a technology-intensive knowledge-driven economy, which will increasingly lead to significantly more mental and emotional demands (Turner, Barling \& Zacharatos, 2002). These demands will, in turn, have a detrimental effect on people's subjective experiences of their work (Baruch, 2006; Kidd, 2008).

Considering that the guiding norms and values that shape careers take more than a few years to be modified, Baruch (2006) further posits that people may potentially have less positive work experiences, and experience more crises and dissatisfaction in their working lives. Researchers have also noted that the complexities of the increasingly turbulent career context have had a significant impact on people's career attitudes and affective experiences of their working lives (Arnold \& Cohen, 2008; Barnett \& Bradley, 2007; Kidd, 2008; Pinnington \& Lafferty, 2003). As a result of more frequent career transitions across as well as within organisations the availability of fewer secure and stable employment opportunities, and the growing concern for worker employability in a knowledgedriven economy (Fugate, Kinicki \& Ashforth, 2004), will mean that employees need to be more effective agents in their career decisions and development, and find different ways of proactively fulfilling their career needs (Sinclair, 2009).

Research into the effects of the changing nature of the workplace and careers and the globally changing socio-economic context on the attraction, selection, remuneration, development and retention of valuable skills (talent or human capital), and career development support practices (that address the needs of a culturally and generationally diverse workforce) has become important. The effects of the rapidly changing work context on the employment relationship and the psychological contract will increasingly require research on factors influencing the attraction and retention of valuable and scarce human resources. These factors include aspects such as employees' sense of job security, career embeddedness and organisational commitment, including aspects such as job and employee satisfaction, career well-being, employee engagement, organisational culture and climate and organisational citizenship behaviour (Coetzee, 2010). In addition, post-modern career counselling frameworks that measure and facilitate behavioural attributes and attitudes that enable work and career adjustment, greater career agency and that optimise person-environment fit across the lifespan have become important avenues to explore (Coetzee \&
Roythorne-Jacobs, 2007). Given the important role of managers and leaders in creating the knowledge-based workforce and learning organisations of the future, research into measuring and developing desired behavioural attributes in leaders and teams will continue to be of high importance.

The national research imperatives and the global challenges posed by a turbulent and rapidly changing world of work seem to call for an increase in research relating especially to personnel psychology, organisational psychology, career psychology, psychological assessment, employee and organisational wellbeing and employment relations.

In view of the foregoing, the proposition is made that trends in the research focus areas in the field of I/O psychology will evolve over time to reflect the needs of the particular socioeconomic and socio-political context in which South African organisations conduct their business.

\section{Research problem and objectives}

Notwithstanding numerous publications on the science and practice of $\mathrm{I} / \mathrm{O}$ psychology in the South African context (as indicated by the literature), there seems to be a paucity of literature on how research has evolved since the I/O psychology field's historical inception in 1946. In order to test the proposition formulated for the present study, the specific objective is to explore the proportional frequency of research in the various subdisciplines of the field from 1950 to 2008, and to critically evaluate whether the observed dominant trends in research focus have evolved to keep pace with the pressing challenges and needs of the changing South African work context.

\section{Potential value-add of the study}

Given the paucity of empirical work on historical and current research trends in the field of I/O psychology in South Africa, the findings may provide preliminary insights that add to the body of knowledge concerned with the evolution of the field in the South African context. The insights derived from the findings can be employed by academia and researchers to plan future research initiatives.

\section{What will follow}

In the next section, the research design will be elaborated on and the research approach and method described. The results 
TABLE 3

Dominant research themes in the various Industrial and organisational psychology subdisciplines (1950-1979)

\begin{tabular}{|c|c|c|c|}
\hline Subdiscipline & 1950-1959 & 1960-1969 & 1970-1979 \\
\hline Personnel psychology & 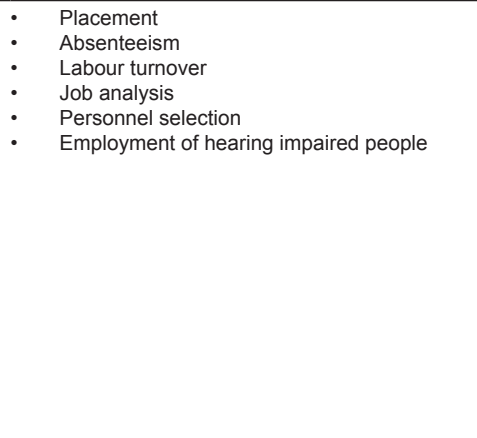 & 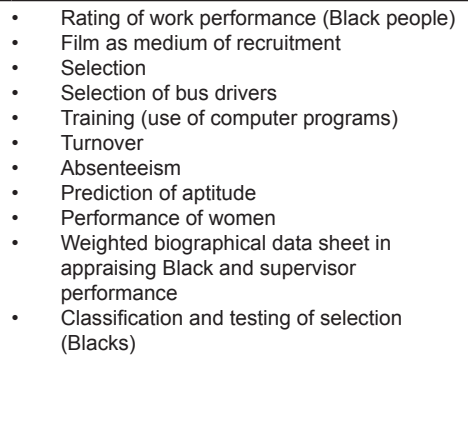 & 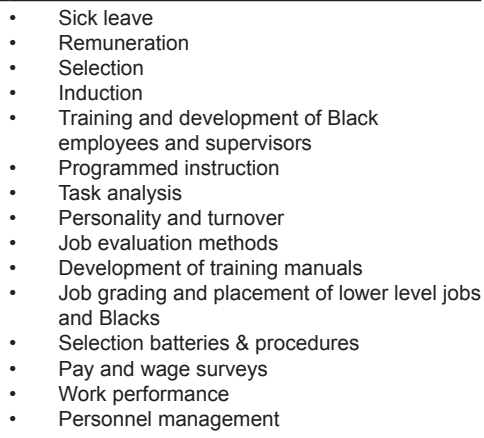 \\
\hline Organisational psychology & $\begin{array}{ll}\text { - } & \text { Organisational morale } \\
\text { - Cultural diversity }\end{array}$ & $\begin{array}{ll}\cdot & \text { Motivation } \\
\dot{*} & \text { Work values } \\
\dot{ } & \text { Group morale } \\
& \text { Cultural diversity }\end{array}$ & $\begin{array}{ll}\text { - } & \text { Motivation of Black employees } \\
\text { - } & \text { Attitudes of Black workers } \\
\text { - } & \text { Role conflict and job satisfaction (Black } \\
\text { - } & \text { Coople) } \\
\text { - } & \text { Leader potential } \\
\text { - } & \text { Productivity } \\
\text { - } & \text { Work behaviour and job characteristics } \\
\text { - } & \text { Industrial morale } \\
\text { - } & \text { Managerial communication }\end{array}$ \\
\hline Career psychology & Personality and occupational adjustment & $\begin{array}{ll}\text { - } & \text { Retirement planning } \\
\text { - } & \text { Vocational guidance } \\
\text { Role conflict (career women) }\end{array}$ & $\begin{array}{ll}\text { - } & \text { Career stages } \\
\text { - } & \text { Occupational choice of women counselling of Black people } \\
\text { - } & \text { Career mobility of Black people and } \\
& \text { graduates }\end{array}$ \\
\hline $\begin{array}{l}\text { Psychometrics/ } \\
\text { Psychological assessment } \\
\text { Employee and organisational } \\
\text { wellness }\end{array}$ & $\begin{array}{l}\text { - } \quad \text { Intelligence measures } \\
\text { - Work adjustment }\end{array}$ & $\begin{array}{ll}\text { - } & \text { Assessment centres for managers } \\
\text { - } & \text { Prediction of managerial performance } \\
& \text { progrion \& test validity of computer } \\
\text { - } & \text { Assessment batteries for bus drivers } \\
\text { - } & \text { Use of TAT in selection of Black people } \\
\dot{-} & \text { Intelligence testing } \\
\text { - Industrial psychological health }\end{array}$ & 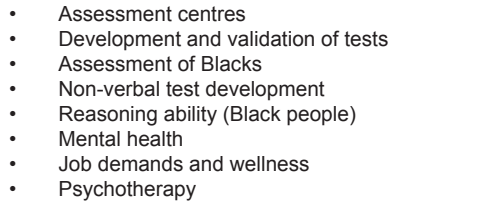 \\
\hline Consumer psychology & none & - $\quad$ none & - Black consumer \\
\hline Ergonomics & Intellectually people with learning disabilities & Accident proneness & $\begin{array}{ll}\text { - } & \text { Effect of noise on concentration } \\
\text { - } & \text { Safety } \\
\text { - } & \text { Human factor in road traffic designs } \\
\text { - } & \text { Fatigue and vehicle accidents }\end{array}$ \\
\hline Employee relations & - none & - none & $\begin{array}{ll}\text { - } & \text { Labour stability and productivity } \\
\text { - } & \text { Industrial relations } \\
& \text { Labour utilisation }\end{array}$ \\
\hline
\end{tabular}

will then be presented and the findings will be discussed. The article concludes with a brief synopsis of the most important conclusions, the limitations of the research design, and recommendations for possible future research initiatives.

\section{RESEARCH DESIGN}

\section{Research approach}

A broad systematic review (Petticrew \& Roberts, 2006) of documented published research on I/O psychology was undertaken.

\section{Research method}

\section{Research boundary}

Being anchored in the academic domain of the field, the boundary of the systematic review was defined to include only documented published research in the field of I/O psychology in South Africa. This included published research articles from 1950 to 2008 from peer-reviewed accredited South African journals and documented completed masters' dissertations and doctoral theses at South African universities. The latter were treated as the sources of data and the identified themes were treated as the data.

\section{Data collecting}

A search was carried out using an online information technology service, the South African Bibliographic Information Network (SABINET). Within the context of the stated boundary of the research, the data included studies carried out during the past 58 years in $\mathrm{I} / \mathrm{O}$ psychology.

\section{Data analysis}

A categorisation framework that consisted of the acknowledged subdisciplines of the I/O psychology field outlined in the literature review was established a priori. Given this, the following eight subdisciplines of I/O psychology formed the basis for the categorisation framework used to synthesise the data:

- personnel psychology

- organisational psychology

- career psychology

- psychometrics

- employee and organisational wellness

- consumer psychology

- ergonomics

- employment relations.

By using a focused categorisation process, themes that related to these eight subdisciplines were systematically identified and categorised according to the subdiscipline areas (De Vos, Strydom, Fouche \& Delport, 2002; Petticrew \& Roberts, 2006). The focused categorisation process entailed going through the 
sources of data manually, line by line, to identify the dominant themes, and focusing on the key categories identified for the purpose of this research (Esterberg, 2002). To make it easier to interpret the findings, the time period 1950-2008 was clustered into six time clusters:

- 1950-1959

- 1960-1969

- $1970-1979$

- $1980-1989$

- 1990-1999

- 2000-2008.

Strategies used to ensure data quality and reporting In view of the qualitative nature of the research approach, it was necessary to take into account concerns regarding the reliability, validity and objectivity of the study. While it is widely agreed that concerns of reliability, validity and objectivity are inherent in research of any kind (Barnard \& Fourie, 2007; Mouton, 1996; Patton, 2002), the nature of the qualitative research paradigm implies a reasonable degree of freedom in the interpretation of data and the resultant personal construction of inferred meaning. Since researchers working within the qualitative research paradigm accept that perfect degrees of reliability and validity can never be achieved, they tend to focus on the following: considerations of trustworthiness or credibility, true value, creativity in the research approach, triangulation and reflection on the research endeavour in its entirety, as well as best practice (Barnard \& Fourie, 2007; Patton, 2002).

To improve the validity and reliability of the present study databases were systematically reviewed and synthesised by using a pre-established widely acknowledged categorisation framework. The objectivity and trustworthiness of the data analysis process were maximised by involving three researchers who were all experienced in systematic data analysis, ensuring they discussed their own possible biases throughout, and continually looking for evidence that either contradicted or confirmed the themes. The average agreement rate was $98 \%$ (i.e. $98 \%$ of the factors were allocated to the same theme categories by each researcher). As a form of researcher triangulation, comments from researchers on the evolution of and challenges in the I/O psychology field (Augustyn \& Cillié, 2008; Bergh 2009; Rothmann \& Cilliers, 2007; Schreuder, 2001; Van Vuuren, 2006) were also considered in the interpretation of the findings. All data was retained for possible future scrutiny.

\section{Presentation of the data}

The results of the systematic review are presented in terms of the chosen categorisation framework. Descriptive statistics frequencies and core themes are used to present the dominant research trends. In terms of core research themes, themes representing less than $10 \%$ have not been included in order to simplify the tables (Table 3 and Table 4 ).

\section{FINDINGS}

Table 2 provides an overview of general (South African) research frequency trends in the various subdisciplines of I/O psychology from 1950 to 2008 within the six predetermined time clusters. The dominant research themes within the various time clusters are presented in Tables 3 and 4.

\section{0-1959 and 1960-1969}

Table 2 shows that research during the two time clusters 19501959 and 1960-1969 was dominated by studies in personnel psychology $(n=18)$. Table 3 shows that dominant themes mostly concerned I/O psychology activities relating to job analysis, fatigue in industry, individual differences, labour turnover, the employment of hearing impaired people, adjustment to work (with special reference to people with disabilities and the causes of accidents). Articles were mostly published in the Journal
Rehabilitation in $S A$, which seems to be the only accredited journal available at that time for scientific publications. Career psychology $(n=4)$ and psychometrics/psychological assessment $(n=5)$ were also popular fields for research during this period. The first doctorate in industrial psychology with the title 'Die opleiding van kleurlingtoesighouers in ' $n$ klerefabriek' (The training of coloured supervisors in a clothing factory) - a theme relating to personnel psychology - was awarded by the University of Stellenbosch to G.F. de W. Steyn in 1957.

\section{0-1979}

As shown in Table 2, during this period 121 research projects in I/O psychology were done mainly in personnel psychology $(n=$ $65)$ and psychological assessment $(n=22)$. Except for the Journal Rehabilitation in SA, journals such as Psychologia Africana, South African Journal of Psychology, Business Alert, South African Journal of Labour Relations and Tydskrif vir Geesteswetenskappe were used for publication purposes. Table 3 shows that the themes that dominated during this time cluster related to I/O psychology activities concerned with sick leave, work motivation, remuneration, selection, career stages and mental health.

\section{0-1989}

Table 2 shows that during this time cluster the number of published research projects increased to 540. Topics researched included especially issues in personnel psychology $(n=175)$, organisational psychology $(n=106)$ and psychological assessment $(n=90)$. The Journal of Industrial Psychology was established during this period (1986) and the majority of the research was published in this journal.

The introduction of the Journal of Industrial Psychology was a major development in that this was the first journal that was dedicated to publish research results in the field of $\mathrm{I} / \mathrm{O}$ psychology. Table 4 shows that themes that dominated during this time cluster related to I/O psychology activities concerned with employee wellness constructs such as locus of control and coping with change, career planning, career advancement, performance appraisal, assessment centres, job analysis, manpower planning, work motivation, remuneration, midcareer transition, organisational climate and change (including resistance to change).

\section{0-1999}

Table 2 shows that from 1990 to 1999 the number of published research projects (articles, masters' dissertations and doctoral theses) increased to 865 . Research was dominated by studies in organisational psychology $(n=201)$, psychometrics $(n=190)$ and employee and organisational wellness $(n=175)$. Studies in the other subdisciplines were proportionally about equally spread. Studies in employee and organisational wellness started to become very popular during this time cluster. Judging by the research topics listed in Table 4, wellness-related constructs such as job stress, role stress, stress management, stress and trauma, burnout and coping were frequent topics selected for research. Other dominant themes were career anchors, career development, personality, leadership, predicting managerial success, organisational change, assessment centres, performance motivation, prediction of work success, job satisfaction, communication and training.

\section{0-2008}

Table 2 shows that the number of completed research projects increased to 938 during this time cluster and predominantly consisted of research in the following subdisciplines:

- employee and organisational wellness $(n=248)$

- organisational psychology $(n=247)$

- $\quad$ psychometrics $(n=193)$.

Table 4 shows that during this time cluster there was an explosion of research on topics like emotional intelligence, leadership, personality, and burn-out and stress. 
TABLE 4

Dominant research themes in the various Industrial and organisational psychology subdisciplines (1980-2008)

\begin{tabular}{|c|c|c|c|}
\hline Subdiscipline & $1980-1989$ & $1990-1999$ & $2000-2008$ \\
\hline Personnel psychology & 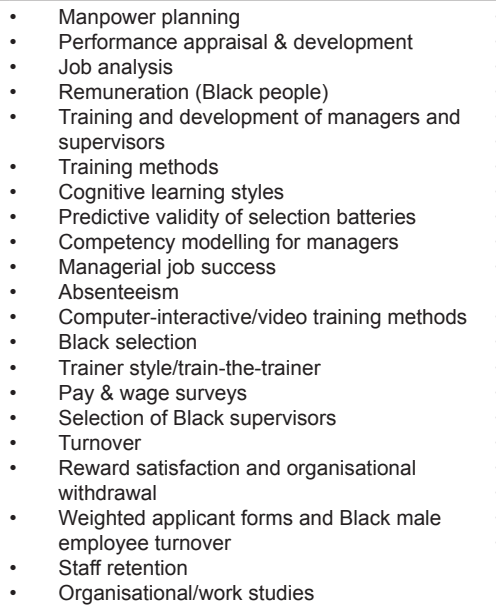 & 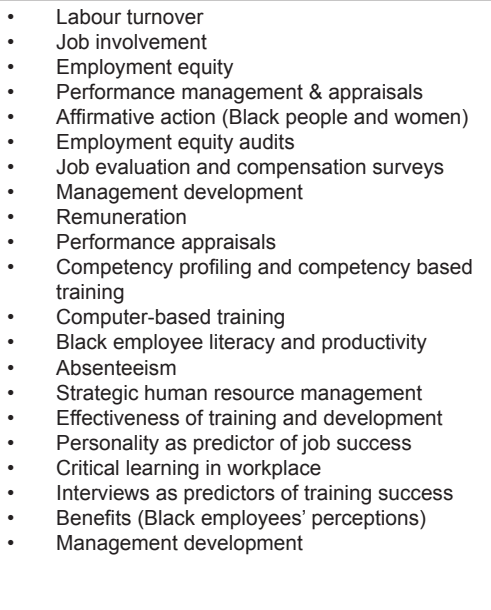 & 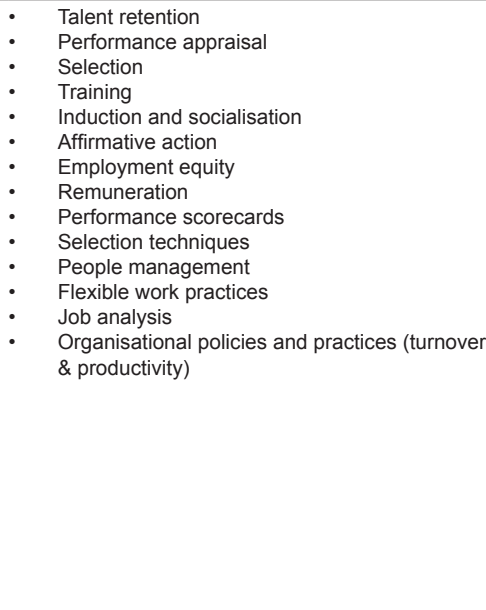 \\
\hline $\begin{array}{l}\text { rganisational } \\
\text { ychology }\end{array}$ & 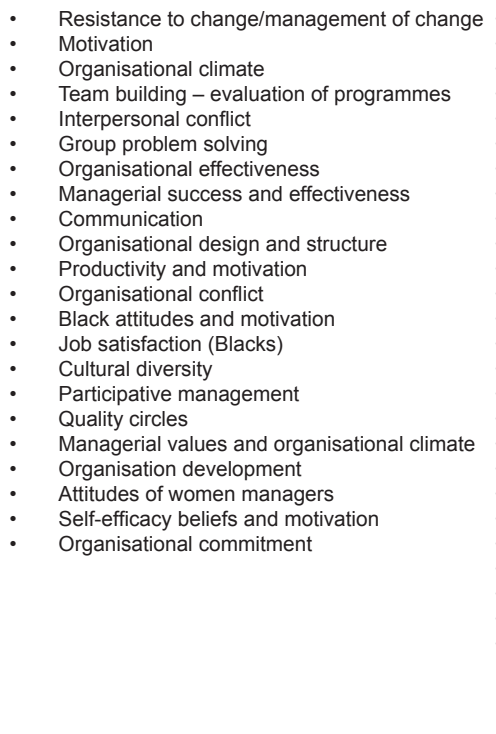 & 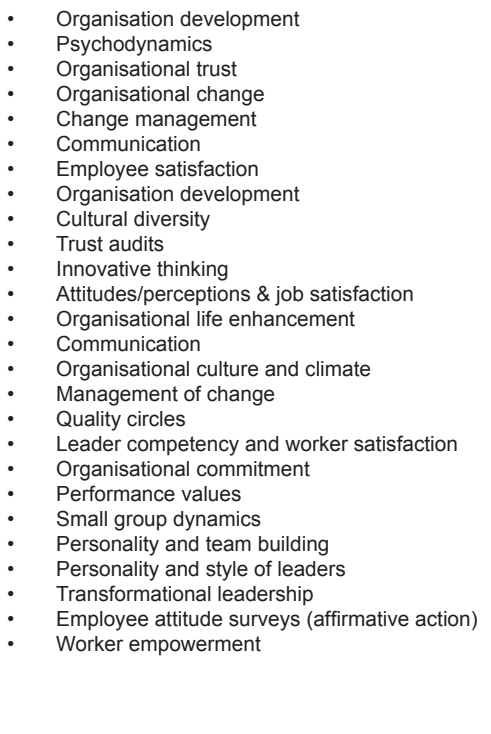 & 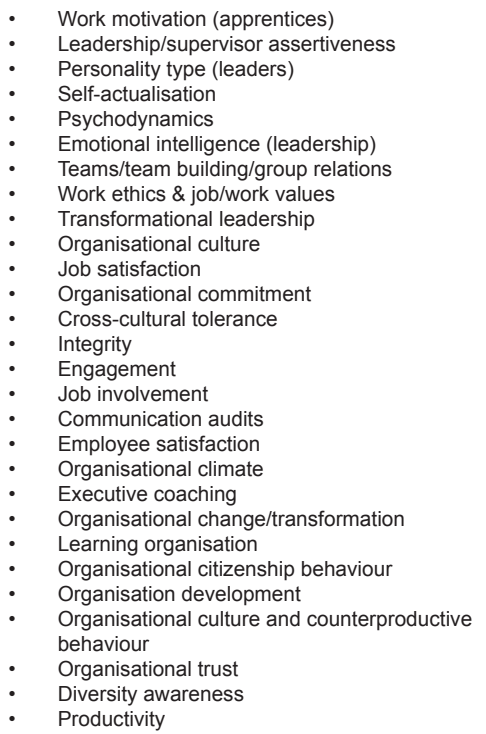 \\
\hline Career psychology & 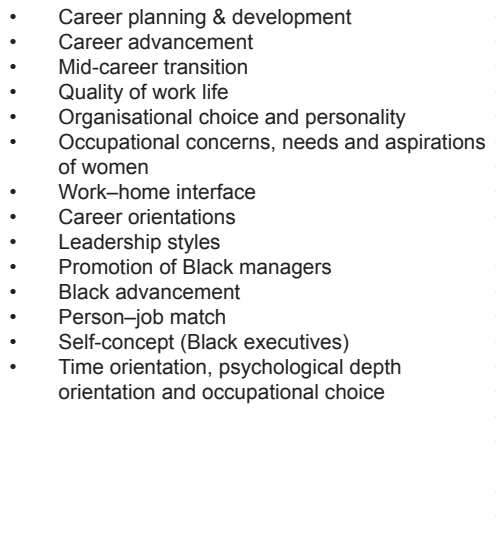 & 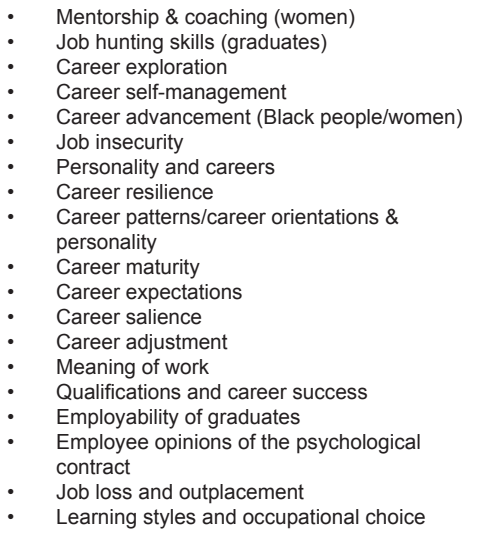 & 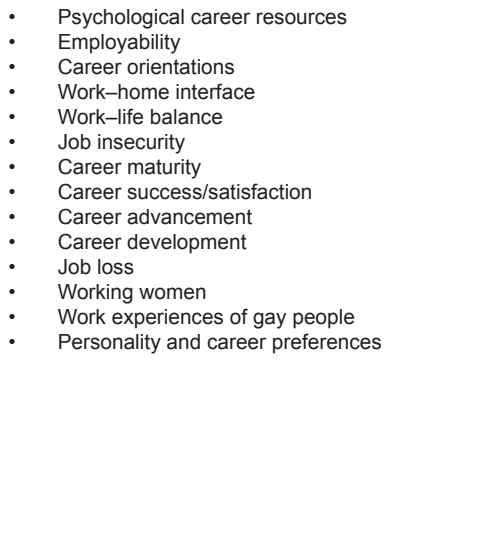 \\
\hline $\begin{array}{l}\text { Psychometrics/ } \\
\text { Psychological } \\
\text { assessment }\end{array}$ & $\begin{array}{ll}\text { - } & \text { Assessment centres (managerial potential) } \\
\text { - } & \text { Uevelopment and validation of tests } \\
\text { - } & \text { Assessing workplace literacy } \\
\dot{*} & \text { Aptitude testing } \\
\dot{\text { - }} & \text { Assessing mental alertness, e.g. bus drivers } \\
\text { - } & \text { Assessing assertiveness of Black employees }\end{array}$ & $\begin{array}{ll}\text { - } & \text { Assessment centres (leader potential) } \\
\text { - } & \text { Development and validation of tests } \\
\text { Assessment of mental alertness, and work } & \text { performance of supervisors } \\
\text { - } & \text { Assessment of psychological optimal } \\
\text { functioning } \\
\text { - } \quad \text { Work adjustment } \\
\text { - } \quad \text { Pairness of selection batteries } \\
\text { - } \quad \text { Emotional intelligence and leadership } \\
\text { - Personality profiles of leaders } \\
\text { Brain preferences and managerial } \\
\text { effectiveness }\end{array}$ & $\begin{array}{ll}\text { - } & \text { Assessment centres } \\
\text { - } & \text { Mevelopment and validation of tests } \\
\text { - } & \text { Validity of structured employment interviews } \\
\text { - Structural equivalence of psychometric tests }\end{array}$ \\
\hline
\end{tabular}




\begin{tabular}{|c|c|c|c|}
\hline \multicolumn{4}{|c|}{$\begin{array}{l}\text { TABLE } 4 \text { (CONTINUES...) } \\
\text { Dominant research themes in the various Industrial and organisational psychology subdisciplines (1980-2008) }\end{array}$} \\
\hline $\begin{array}{l}\text { Employee and } \\
\text { organisational wellness }\end{array}$ & 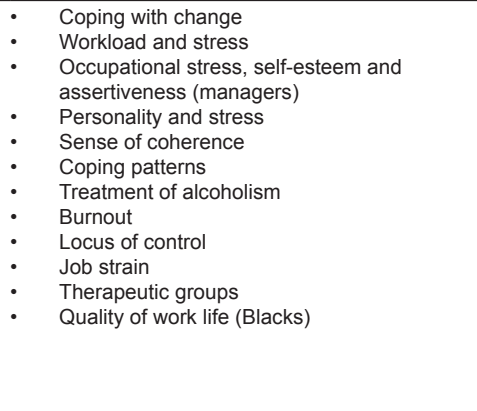 & 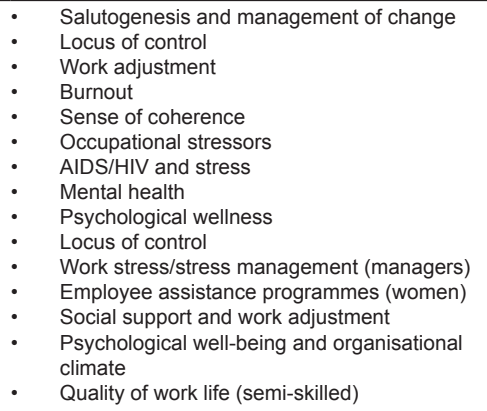 & $\begin{array}{ll}\dot{\cdot} & \text { Stress and burnout } \\
\dot{\cdot} & \text { Psychoneuro-immunology and stress } \\
\dot{\cdot} & \text { Stress management } \\
\dot{\cdot} & \text { Sellness } \\
\dot{\cdot} & \text { Coping - psychological factors } \\
\dot{\cdot} & \text { Locus of control } \\
\dot{\cdot} & \text { Positive psychology } \\
\dot{\cdot} & \text { Job demands } \\
\dot{\cdot} & \text { Job resources } \\
\cdot & \text { Work wellness } \\
& \text { Employee assistance programmes }\end{array}$ \\
\hline Consumer psychology & $\begin{array}{ll}\text { - } & \text { Consumer markets } \\
\text { - } & \text { White and Black consumers } \\
\text { - } & \text { Advertising } \\
\text { - } & \text { Image studies } \\
\text { - } & \text { Client service } \\
\text { - } & \text { Market segmentation and socio-cultural } \\
\text { - } & \text { characteristics } \\
& \text { Symbolism in advertising }\end{array}$ & $\begin{array}{ll}\text { - } & \text { Service delivery/client service } \\
\text { - } & \text { Sales performance and client needs } \\
\text { - } & \text { Consume of urban Black consumers } \\
\text { - } & \text { Consumer attitudes towards advertising and } \\
\text { branding } & \\
\text { - } & \text { Attitudes - television advertising }\end{array}$ & $\begin{array}{ll}\cdot & \text { Service delivery } \\
\cdot & \text { Consumer decision making } \\
\text { branding }\end{array}$ \\
\hline Ergonomics & $\begin{array}{ll}\text { - } & \text { Accident rates/pedestrian safety } \\
\text { - } & \text { Accident proneness (personal and moral } \\
\text { development) } \\
\text { - }\end{array}$ & $\begin{array}{ll}\text { - } & \text { Noise, lightning, dust \& sick building } \\
& \text { syndrome } \\
\text { - } & \text { Ergonomic factors } \\
\text { - } & \text { Personality in ergonomics } \\
\text { - Occupational safety }\end{array}$ & $\begin{array}{ll}\text { - } & \text { Ergonomic factors } \\
\text { - } & \text { Occupational safety } \\
\text { Bus driver safety }\end{array}$ \\
\hline Employee relations & 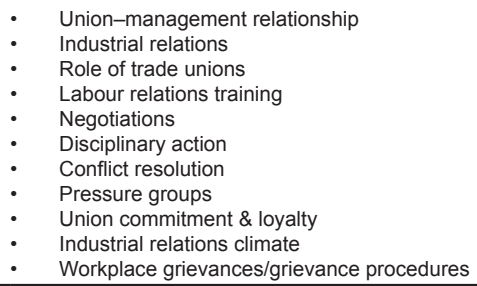 & 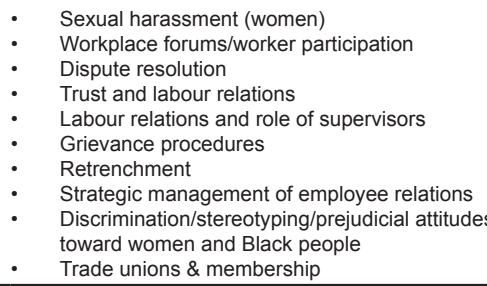 & $\begin{array}{ll}\text { - } & \text { Retrenchments and psychological fitness } \\
\text { - } & \text { Retrenchments and job loss } \\
& \text { New labour legislation }\end{array}$ \\
\hline
\end{tabular}

\section{DISCUSSION}

The objective of the present study was to explore the proportional frequency of documented published research (articles, and masters' dissertations and doctoral theses) in the various subdisciplines of I/O psychology from 1950 to 2008, and to critically determine whether the dominant trends in the research focus areas have evolved to keep pace with the pressing challenges and needs of a changing work and socioeconomic context. Overall, the findings indicate a noteworthy proportional decrease in personnel psychology research (since 1990); and a proportional increase in published research relating to organisational psychology (since 1980), and employee and organisational wellness (since 1990). Robbins and Judge (2009) note that since the 1980s the development of managers has received high priority, to help organisations attract and retain high-performing employees. Regardless of labour market conditions, outstanding employees and managers are always in short supply. Themes such as organisational culture and climate, leader behaviour and development, employee satisfaction and commitment will continue to be of importance in the attraction and retention of valuable talent. The proportional increase in employee and organisational wellness research is in line with the increasing concern regarding the impact of changes in the nature of jobs and careers due to rapid technological and socio-economic changes on the well-being of individuals and organisations (Rothmann \& Cilliers, 2007).

The proportional explosion of research on employee and organisational wellness from 1990 onwards is conspicuous and seems to be a global trend. Schaufeli (2003) claims that from 1990 until 2003 over 6000 scientific publications with 'burnout' in the title were published internationally. This trend could be attributed to the emergence of the so-called positive psychology paradigm (Coetzee \& Viviers, 2007) and the continuing demands of a globally turbulent, highly competitive business environment that impacts on both employee and organisational wellness (Rothmann \& Cilliers, 2007). However, when one considers the national research imperatives for human capital development and the attraction, selection, remuneration, development and retention of scarce skills in a knowledgedriven economy (DST, 2008), the proportional decrease in research related to personnel psychology is a cause for concern.

The findings further show a noteworthy proportional increase in psychological assessment research since 1990. This trend is in line with Landy and Conte's (2010) observation that personality characteristics are assuming an increasingly important role in understanding and predicting work behaviour in multi-cultural societies and work places. Documented published research in career psychology seems to be consistently proportionally low throughout all six time clusters, and very little research was documented in the areas of consumer psychology, ergonomics and employment relations throughout the various time clusters. The consistent lack of published career-related research in the South African organisational context is also a cause for concern. The changing nature of work and careers in a multi-cultural and multi-generational work context has, for many people, made some motivational and career development theories less relevant. This, in turn, calls for new theories and measures to encourage greater career agency and career self-management (Bergh, 2009). Furthermore, the increased use of technology in the execution of personnel functions such as recruitment, selection, performance management, training and development raises concerns regarding the human-machine interaction and seems to call for more research into the whole area of ergonomics. Also, the decreasing value of the psychological contract and increasing considerations for ethical, human rights and legal issues in the South African employment equity context call for more research to be undertaken into employment relations (Bergh, 2009). 
The increasing amount of research being undertaken in the subdiscipline organisational psychology reflects the continuing needs of businesses to remain effective and productive. The trends further show that psychometrics continues to remain important, especially the ongoing revision of the validity of psychometric measures for diverse groups of populations and generations in the workplace. According to Bergh (2009), ongoing consideration should be given to the role of psychometrics in I/O psychology, and how validity indications are interpreted and used in terms of new predictor criteria for job, work and career success. Consideration should also be given to the relationship between employee attributes and work performance in a technology-intensive work environment.

In the light of the trends revealed in the findings of this study the proposition that trends in the research focus areas in the field of I/O psychology will evolve over time to reflect the needs of the particular socio-economic context is only partially accepted.

\section{Conclusion}

In the light of the findings of this study it can be concluded that I/O psychology research in South Africa appears to be in line with international trends in I/O psychology research focus areas, which could be attributed to the demands and challenges posed by the changing business environment. However, although the number of published scientific articles and masters' dissertations and doctoral theses has shown a steady proportional increase from 1950 to 1990 (with an explosion in research outputs between 1990 and 2008), the relevance and value added by the research to the practical realities, and especially the challenges of the work place today, are open to debate.

The imbalance of research trends revealed by the findings and the reoccurrence of many 'popular' themes in the various time clusters of the subdisciplines should be considered in the light of Dunnette's (1966) and Augustyn and Cillié's (2008) criticism that research at academic institutions might often not be needsdriven or problem-orientated, but instead be a function of data availability. As a result available data are often recycled in the pursuit of 'hot topics' in the field at certain periods of time. Although the research might be scientifically correct it is imperative that researchers in the I/O psychology field critically reflect on the relevance and the value added by their research in terms of solving people-related business issues in the real world (Augustyn \& Cillié, 2008; Landy \& Conte, 2004).

Renecle (2001) states that for the field of I/O psychology to have an optimal impact it will be necessary to continuously predict the needs based on changes in the business environment. If the field is to remain relevant it should develop its capacity to face up to the emerging challenges of a technology-intensive knowledge-based economy and strive to align its research agenda to national and business imperatives, especially the challenges posed by the unique socio-political and socioeconomic demands of a post-apartheid South Africa. According to Moalusi (2001), the academic research community should respond positively to the needs expressed by industry. Concerted efforts should be made to bridge the gap between theory and practice by dealing with issues that are pertinent to the workplace. Paying attention to the issues relevant to the South African workplace will help to create the much needed balance between theory and practice, that is, between the ideal and reality. Van Vuuren (2006) also emphasises that the academic research community should continuously reflect on its identity and the relevance of I/O psychology research on the communities it serves.

\section{Limitations and recommendations for future research}

The limitations of the present study should be interpreted in the light of the stated purpose and objective of the study. It should be pointed out that the present study was approached from an academic perspective and did not include unpublished research. Using the SABINET portal to access documented published peer-reviewed accredited South African journals and documented completed masters' dissertations and doctoral theses at South African universities necessarily excluded both other research-related national and international publications and unpublished research.

Notwithstanding the criticisms raised by researchers in the field and the limitations of the present study, the findings provide valuable preliminary insights that add to the body of knowledge that focuses on the evolution of I/O psychology in South Africa. The insights derived from the findings can be employed by academia and researchers in the field to plan future research directions. Such research directions should take cognisance of the challenge for I/O psychology research to remain relevant, needs-driven and problem-orientated. It is anticipated that I/O psychology research will remain important to organisations because, as Landy and Conte (2004) point out, every course of action that an organisations decides on is, in effect, a prediction or an anticipation of a given outcome. The better the research base that supports that prediction, the more confident the organisation can be of the outcome. As such, the challenge for the I/O psychology research agenda lies in the capacity and willingness of both academia and practitioners in the field to heal the rift between science and practice, and adopt new perspectives in the pursuit of research questions that address the real-world needs of a post-modern South African business society.

\section{REFERENCES}

Arnold, J., \& Cohen, L. (2008). The psychology of careers in industrial and organisational settings: A critical but appreciative analysis. In G.P. Hodgkinson \& J.K. Ford (Eds), International review of Industrial and Organisational Psychology, Vol. 23 (pp. 1-43). London: John Wiley \& Sons.

Arnold, J., \& Randall, R. (2010). Work psychology: Understanding human behaviour in the workplace. (5th edn.). Harlow, Essex: Pearson Education.

Augustyn, J.C.D., \& Cillié, G.C. (2008). Theory and practice in industrial psychology: Quo Vadis? SA Journal of Industrial Psychology, 34(1), 70-75.

Barnard, G., \& Fourie, L. (2007). A conceptual framework to explore the roles and contributions of industrial psychologists in South Africa. SA Journal of Industrial Psychology, 33(2), 34-44.

Barnett, B.R., \& Bradley, L. (2007). The impact of organisational support for career development on career satisfaction. Career Development International, 12(7), 617-636.

Baruch, Y. (2004). Transforming careers: From linear to multidirectional career paths. Career Development International, 9(1), 58-73.

Baruch, Y. (2006). Career development in organizations and beyond: Balancing traditional and contemporary viewpoints. Human Resource Management Review, 16, 125-138.

Bergh, Z.C. (2009). Fields of study and practice areas in industrial and organisational psychology. In Z.C. Bergh \& A.L. Theron (Eds.), Psychology in the work context (pp. 16-29). Cape Town: Oxford University Press.

Biesheuvel, S. (1984). Work motivation and compensation: Motivational aspects, Vol. 1. Johannesburg: McGraw-Hill.

Cascio, W.F. (2001). Knowledge creation for practical solutions appropriate to a changing world of work. SA Journal of Industrial Psychology, 27(4), 14-16.

Coetzee, M. (2010). Psychology of retention. In M. Coetzee \& A.M.G. Schreuder (Eds.), Personnel psychology: An applied perspective. Cape Town: Oxford University Press.

Coetzee, M., \& Roythorne-Jacobs, H. (2007). Career counselling and guidance in the workplace: A manual for career practitioners. Cape Town: Juta. 
Coetzee, M., \& Schreuder, A.M.G. (2010). Personnel psychology: An applied perspective. Cape Town: Oxford University Press.

Coetzee, S., \& Viviers, A.M. (2007). An overview of research on positive psychology in South Africa. South African Journal of Psychology, 37(3), 470-490.

Coutinho, M.T., Dam, U.C., \& Blustein, D.L. (2008). The psychology of working and globalisation: a new perspective for a new era. International Journal of Educational and Vocational Guidance, 8, 5-18.

Department of Higher Education and Training (DHET). (2010). Framework for the National Skills Development Strategy 2011/12-2015/16. Pretoria: Department of Higher Education and Training.

Department of Science and Technology (DST). (2008). Corporate Strategy 2008/2009. Pretoria: Department of Science and Technology.

De Vos A.S., Strydom, H. Fouche, C.B., \& Delport, C.S.C. (2002). Research at grass roots: For the social sciences and human service profession. (2nd edn.). Pretoria: Van Schaik.

Dunnette, M.D. (1966). Fads, fashions and folderol in psychology. American Psychologist, 12, 343-352.

Dunnette, M.D. (1990). Blending science and practice of industrial psychology: Where are we and where are we going? In M.D. Dunnette \& L. Hough (Eds.), Handbook of industrial and organisational psychology, n.p., Vol 1. Palo Alto: Consulting Psychologists Press.

Esterberg, K.G. (2002). Qualitative methods in social research. Toronto: McGraw-Hill.

Fugate, M., Kinicki, A.J., \& Ashforth, B.E. (2004). Employability: A psycho-social construct, its dimensions, and applications. Journal of Vocational Behaviour, 65, 14-38.

Katzell, R.A., \& Austin, J.T. (1992). From then to now: The development of industrial-organisational psychology in the United States. Journal of Applied Psychology, 77(6), 803-835.

Kidd, J.M. (2008). Exploring components of career wellbeing and the emotions associated with significant career experiences. Journal of Career Development, 35(2), 166-186.

Landy, F.J., \& Conte, J.M. (2004). Work in the 21st century: An introduction to industrial and organisational psychology. (4th edn.). New York: McGraw-Hill.

Landy, F.J. \& Conte, J.M. (2010). Work in the 21st century. (5th edn.). Hoboken: John Wiley \& Sons.

Levy, P.E. (2006). Industrial/Organisational psychology: Understanding the workplace. (2nd edn.). New York: Houghton Mifflin.

Marshall, V., \& Bonner, D. (2003). Career anchors and the effects of downsizing: Implications for generations and cultures at work: A preliminary investigation. Journal of European Industrial Training, 27(6), 281-291.

McCleod, D. (1995). The ergonomics edge. New York: Van Nostrand Reinhold.

Moalusi, K.P. (2001). Repositioning industrial psychology for the creation of new futures in turbulent times. SA Journal of Industrial Psychology, 27(4), 17-21.

Mouton, J. (1996). The nature and structure of the practice of science. In J. Garbers (Ed.), Effective research in the social sciences. n.p. Pretoria: Van Schaik.

Muchinsky, P.M., Kriek, H.J., \& Schreuder, D. (2005). Personnel psychology. Cape Town: Oxford.
Patton, M.Q. (2002). Qualitative research and evaluation methods. Thousand Oaks: Sage.

Petticrew, M., \& Roberts, H. (2006). Systematic reviews in the social science: a practical guide. Oxford: Blackwell.

Pietersen, H.J. (2005). Knowledge development in industrial/ organisational psychology (South Africa). SA Journal of Industrial Psychology, 31(2), 78-85.

Pinnington, A., \& Lafferty, G. (2003). Human resource management in Australia. New York: Oxford University Press.

Raubenheimer, I. van W. (1974). Enkele gedagtes oor die opleiding van bedryfsielkundiges in Suid Afrika [Some thoughts on the training of industrial psychologists in South Africa]. Unpublished manuscript, Sirsa, Bloemfontein.

Renecle, S.D. (2001). The relevance of industrial psychology as a profession and discipline in South Africa. SA Journal of Industrial Psychology, 27(4), 22-24.

Riggio, R.E. (2009). Introduction to Industrial/Organisational Psychology. London: Pearson.

Robbins, S.P., \& Judge, T.A. (2010). Essentials of Organisational Behavior. New York: Pearson.

Rothmann, S., \& Cilliers, F.V.N. (2007). Present challenges and some critical issues for research in industrial/ organisational psychology in South Africa. SA Journal of Industrial Psychology, 33(1), 8-17.

Schreuder, A.M.G., (2001). The development of industrial psychology at South African universities: A historical overview and future perspective. SA Journal of Industrial Psychology, 27(4), 2-7.

Schreuder, A.M.G. \& Coetzee, M. (2009). A historical overview of research on I/O Psychology in South Africa. Poster presented at SIOPSA 12th Annual Conference, June, CSIR, Pretoria.

Sinclair, V. (2009). Experiencing career satisfaction and career success over the life span. Retrieved on February 02, 2010, from http://www.counselling-directory.org.uk/ counselloradvice98889.html

Society for Industrial and Organisational Psychology (SIOP). (1999). Guidelines for education and training at the doctoral level in industrial/organizational psychology. Bowling Green: SIOP Inc.

Suutari, V., \& Taka, M. (2004). Career anchors of managers with global careers. Journal of Management Development, 23(9), 833-847.

Sweder, R.A., \& Fiske, D.W. (1986). Uneasy social science. In D.W. Fiske \& R.A. Sweder (Eds.), Metatheory in social science: Pluralism and subjectivities. n.p. Chicago: University of Chicago Press.

Turner, N., Barling, J., \& Zacharatos, A. (2002). Positive psychology at work. In C.R. Snyder \& S.J. Lopez (Eds.), Handbook of positive psychology (pp. 715-728). Oxford, UK: Oxford University Press.

Van Vuuren, L. (2006). Industrial psychology: Goodness of fit? Fit for goodness. In inaugural lecture, Department of Industrial Psychology, 06 November 2010. University of Johannesburg: South Africa.

Veldsman, T. (2001). A new playing field, game and/or different rules? Into the future with Industrial Psychology as a discipline and profession. South African Journal of Industrial Psychology, 27(4), 34-41. 